\title{
Erratum to: 'Mutation of epigenetic regulators TET2 and MLL3 in patients with HTLV-I-induced acute adult T-cell leukemia'
}

Chien-Hung Yeh ${ }^{1}$, Xue Tao Bai ${ }^{1}$, Ramona Moles ${ }^{1}$, Lee Ratner ${ }^{2}$, Thomas A. Waldmann ${ }^{3}$, Toshiki Watanabe and Christophe Nicot $^{1 *}$

Unfortunately, the original version of this article [1] contained an error. The author Toshiki Watanabe's first name and surname were placed in the wrong order. Here we have included them in the correct order. There will be an update to go alongside this erratum in correcting this error.

\begin{abstract}
Author details
'Department of Pathology, Center for Viral Oncology, University of Kansas Medical Center, 3901 Rainbow Boulevard, Kansas City, KS 66160, USA. ${ }^{2}$ Department of Medicine, Division of Molecular Oncology, Washington University School of Medicine, Saint Louis, MO 63110, USA. ${ }^{3}$ Lymphoid Malignancies Branch, Center for Cancer Research, National Institutes of Health, Building 10, Room 4 N/115, 10 Center Drive, Bethesda, MD 20892, USA. ${ }^{4}$ Department of Medical Genome Sciences, University of Tokyo, Tokyo, Japan.
\end{abstract}

Received: 25 February 2016 Accepted: 25 February 2016

Published: 2 March 2016

\section{Reference}

1. Yeh C-H, Bai XT, Moles R, Ratner L, Waldmann TA, Watanabe T, et al. Mutation of epigenetic regulators TET2 and MLL3 in patients with HTLV--induced acute adult T-cell leukemia. Mol Cancer. 2016;15:15.

\footnotetext{
* Correspondence: cnicot@kumc.edu

1 Department of Pathology, Center for Viral Oncology, University of Kansas Medical Center, 3901 Rainbow Boulevard, Kansas City, KS 66160, USA
}

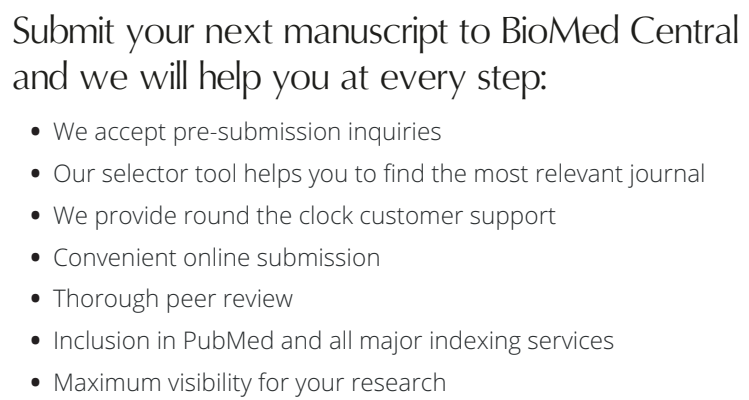

- We accept pre-submission inquiries

- Our selector tool helps you to find the most relevant journal

- We provide round the clock customer support

- Convenient online submission

- Thorough peer review

- Inclusion in PubMed and all major indexing services

- Maximum visibility for your research

Submit your manuscript at www.biomedcentral.com/submit 